\title{
Coping with religious tolerance and gender equality: comparing Islam and good governance perspectives
}

\author{
Ridho Al-Hamdi \\ Department of Philosophy and Political Science, \\ TU Dortmund University, Germany \\ E-mail: ridho.alhamdi@tu-dortmund.de \\ DOI: $10.18326 /$ ijims.v5i2.163-193
}

\begin{abstract}
Using literature review and in-depth analysis, the study is going to examine the comparative perspective between Islam and the West in addressing two main public issues, i.e. religious tolerance and gender equality. More specifically, this study will provide the policy, agenda and strategy of Islam and good governance in coping with those two issues. Therefore, the finding of the study is that Islam and good governance precisely have no distinctive concept, policies, agendas and strategy. In contrast, both of them obviously agree that religious tolerance and gender equality is important for human life sustainability. The result, Muslim communities have to disseminate the notion of the compatibility between Islam and good governance to the world.
\end{abstract}

Menggunakan review literatur dan analisis mendalam, penelitian ini akan menguji perspektif komparatif antara Islam dan Barat dalam menjawab dua masalah umum utama, yaitu toleransi beragama dan kesetaraan gender . Lebih khusus, penelitian ini akan menyoroti kebijakan, agenda dan strategi Islam dan pemerintahan yang baik dalam menjawab dua masalah di atas. Temuan 
studi ini adalah bahwa Islam dan pemerintahan yang baik justru tidak memiliki konsep yang khas, kebijakan, agenda dan strategi. Sebaliknya, keduanya jelas menyepakati bahwa toleransi beragama dan kesetaraan gender penting untuk keberlanjutan kehidupan manusia. Hasilnya, masyarakat Muslim harus menyebarluaskan gagasan kompatibilitas antara Islam dan pemerintahan yang baik kepada dunia.

Keywords: Religious tolerance; Gender equality; Islam; Good governance

\section{Introduction}

In spite of a whole religion, in fact Islam frequently deals with a range of problems and barriers. Religious tolerance and gender equality are appealing issues which can be studied further, because these two issues are still debatable amongst society. Some schools in Muslim communities concur with the notion and practices on religious tolerance and gender equality while others still in the opposite side. The last view believe that Islam is the most comprehensive religion in the world and there is no equality between men and women because women always behind the men. Therefore, this study is going to trace back Islamic tenets on religious tolerance and gender equality as well as to compare it with western's good governance perspective. Using a literature review and in-depth analysis, the study attempts to explain comparatively the policy, agenda and strategy of Islam and good governance in dealing with religious tolerance and gender equality issues.

Some technical definitions will be provided here. The policy is a set of interrelated decisions regarding the selection of goals and the ways of obtaining them within a specified situation. ${ }^{1}$ The agenda denotes to a set

\footnotetext{
${ }^{1}$ W.I. Jenkins, Policy Analysis: A Political and Organizational Perspective, New York: St. Martin's Press, 1978, 15. See, Thomas R. Dye, Understanding Public Policy, Englewood Cliffs, N.J.: Prentice-Hall, 1984, 1.
} 
of public issues as the application of the policy to be pursued. It is typically more specific and operational statements than the policy. In other words, the agenda consists of programs and activities. In the meantime, the strategy is the way it operates the agenda by interrelated-ways. There are four main sections in this study. First is explaining the similarity between Islam and democracy. Second is defining Islam and good governance. Third is portraying the policy, agenda and strategy of Islam and good governance in addressing religious tolerance issues. Fourth is depicting the policy, agenda and strategy of Islam and good governance in handling gender equality issues.

\section{Islam and democracy in scholarly discourse}

The discourse on Islam and democracy has been at the heart of intellectual debate in Muslim and West world since the nineteenth century. Previous studies demonstrated that there are two main distinctive kinds of school of thought regarding the relationship between Islam and democracy. The school that Islam is incompatible with democracy can be reflected in works by Huntington (1984, 1991), Kedourie (1992), Fukuyama $(1992,2001)$ and Lewis (2002). These scholars believe that Islam is inimical to democracy, because they are distinctive creatures. Meanwhile, the opposite view that Islam definitely has a positive culture with democracy can be represented by Rubenstein (1994), Anderson (1995), Halliday (1996), Entelis (1997), Gerges (1999), Rose (2002), Said (2002), Fish (2002), Tessler (2002), Al-Braizat (2002), and Norris and Inglehart (2003) who theorise that the absence of democracy in Muslim states is not associated with Islam, but with non-Islamic factors such as social and political economy, geopolitics and international factors. The last perspective is also reinforced by Esposito and Voll (1996), Hefner (2000; 2009), Mousalli (2001), Mujani (2003), Abulbaki (2008), Akyol (2009) and Achilov (2010) 
who postulate that Islam as a political culture has positive values for democracy even with the capitalism.

Huntington argues that the prospect of democracy in Muslim countries particulalry those in the Arab land or the Middle East seem low. The Islamic resurgence and the rise of fundamentalist movements would seem to diminish democratic development particularly since democracy is frequently identified with the extremely Western. Moreover, Huntington portrays that many Muslim states are very poor. Meanwhile, those that are rich are so due to oil, which is controlled by state so that they enhance the power of the state and bureaucracy. Besides, Saudi Arabia and some of the smaller Arab oil-rich Gulf countries have made some modest gestures regarding the introduction to democratic institutions, but these have frequently been failed. ${ }^{2}$ Therefore, Huntington believes that the main obstacle to democratisation in Muslim countries was the absence Western states in promoting democracy. ${ }^{3}$

One serious impediment to democratisation in Muslim countries is the weakness of real commitment to democratic values among its political leaders. They have a good reason to advocate democracy when they are in the out of office, conversely, they fail when they are in the office. It can be proven that a number of elected leaders in Asia and the Middle East, of course, can become examples: Syngman Rhee and Park Chung Hee in Korea, Adnan Menderes in Turkey, Ferdinand Marcos in the Philippines, Lee Kwan Yew in Singapore, Indira Gandhi in India and Sukarno in Indonesia. These leaders won power through the electoral system, but they used their power to undermine that system. They had a tiny commitment to democratic values and practices. In fact, it is hard to

\footnotetext{
2 Samuel P. Huntington, "Will More Countries Become Democratic?", Political Science Quarterly, Volume 99 (1984), 216.

${ }^{3}$ Samuel P. Huntington, The Third Wave: Democratization in the Late Twentieth Century, Norman: University of Oklahoma Press, 1991, 289.
} 
identify any Arab or Muslim leaders who made a reputation as an advocate of democracy while in the office. ${ }^{4}$

Kedourie posits that Islamic beliefs, norms, attitudes, and experience have shaped a distinctive view of politics. Muslims are proud of their heritage and closed to the outside world. This civilisation constrains Muslims from learning about and appreciating the social and political progress achieved by others. ${ }^{5}$ Along with Huntington and Kedouri, Lewis assumes that the exclusivity of Islam lies in the fact that religion regulates all aspects of Muslim life. It is unthinkable for Muslims to belong to any social group, enjoy any activities, or develop any aspect of life outside religious regulation and jurisdiction. There is no distinction in Muslim society between the law of religion and the law of the state, which is basic to modern politics. All aspects of Muslim life, including the political, are regulated by a single divine law (shari' $a$ ). Secularism, as a crucial element of modern society and polity cannot be expected to emergence from within the society. Secularism might be imported from the West, but the attempt has sparked widespread rejection from Muslims, reflecting the belief that Islam is a self-sufficient religion which encompasses all aspects of human life. ${ }^{6}$

Furthermore, Fukuyama believes that there have been pressures for greater democracy for various Middle Eastern countries like Egypt and Jordan, following the Eastern European revolutions of 1989. But in this part of the world (Middle East), Islam has stood as a major barrier to democratisation. As demonstrated by the Algerian municipal elections of 1990, or by Iran, greater democracy may not lead to greater

\footnotetext{
${ }^{4}$ Samuel P. Huntington, The Third Wave..., 297-298.

${ }^{5}$ Elie Kedourie, Politics in the Middle East, Oxford: Oxford University Press, 1992, 1.

${ }^{6}$ Bernard Lewis, What Went Wrong? Western Impact and Middle Eastern Response, Oxford: Oxford University Press, 2002, 100.
} 
liberalisation because it brings to power Islamic fundamentalists hoping to establish some form of popular theocracy. ${ }^{7}$ A month after the 9/11 tragedy which attacted twin towers in the United States of America, Fukuyama forcefully claims that there does seem to be something about Islam, or at least the fundamentalist versions of Islam which have been dominant in recent years, that makes Muslim societies particularly resistant to modernity. In Fukuyama's view, modernity can be characterised by liberal democracy and capitalism. ${ }^{8}$

The second view has opposite conclusions about Islam and democracy. Norris and Inglehart discover that there is no significant difference in support for democratic values among Muslims and non-Muslims. Muslims, like non-Muslims throughout the world, positively support democratic institutions. ${ }^{9}$ Through his straightforward cross-national research, Fish urges that although Muslim countries are poorer and more authoritarian than non-Muslim countries, the test provides strong support for the hypothesis that Muslim countries are democratic underachievers. Besides, interpersonal trust in Muslim countries is higher than in Catholic countries. The poblem in Muslim countries only that Muslims are likely not to support the idea and practice of gender equality. However, a case Megawati Sukarnoputri in Indonesia show that democracy's prospect in Musim countries is more favourable. ${ }^{10}$

${ }^{7}$ Francis Fukuyama, The End of History and the Last Man, New York: Three Free Press, $1992,347$.

${ }^{8}$ Francis Fukuyama, “The West Has Won: Radical Islam Can't Beat Democracy and Capitalism”, The Guardian, 11 October 2001.

${ }^{9}$ See, Pippa Norris and Ronald Inglehart, "Islamic Culture and Democracy: Testing the Clash of Civilizations' Thesis", in Ronald Inglehart (Ed.) Human Values and Social Change: Findings from the Values Surveys, Leiden: Brill, 2003.

${ }^{10}$ M. Steven Fish, "Islam and Authoritarianism", World Politics, Volume 55 (October 2002), 4-37. 
Employing World Values Survey data from Egypt, Jordan, Morocco, and Algeria, Tessler attempts to assess the influence of Islamic orientations on attitudes towards democracy. The result shows that strong Islamic attachments is not incompatible with democracy and does not discourage the emergence of attitudes favorable to democracy to any significant degree. He also found that Islam as a set of personal religious practices and political values does not have a significant impact on support for democratic values. ${ }^{11}$ Afterwards, Al-Braizat rejects Fukuyama's claim. He argues that Islam is largely irrelevant as an explanatory variable for democracy or authoritarianism. Concentrating on religion as the sole independent variable or a yardstick could be seriously misleading and spurious. For Al-Braizat, Islam neither explains democracy nor authoritarianism. Support to Nazih Ayubi's theory, he believes that Islam is not a political religion. ${ }^{12}$ Moreover, Mousalli demonstrates that the concepts of shura and ikhtilaf are substantively democratic norms and values. Furthermore, Esposito and Voll refer to ijtihad and ijma' as Islamic norms which substantively reflect democratic culture. They also believe that political participation, as a core concept in democracy, is not an alien concept to Muslims. ${ }^{13}$

Meanwhile, Hefner is optimistic that, based on his sociological and anthropological analysis in Indonesia, Muslim society will encourage democratic culture althought it needs a serious strategy and a long-term time to achieve it. However, he is really certain that the desire for democracy

\footnotetext{
${ }^{11}$ Mark Tessler, "Do Islamic Orientations Influence Attitudes toward Democracy in the Arab World: Evidence for the World Values Survey in Egypt, Jordan, Morocco, and Algeria”, International Journal of Comparative Sociology, Volume 43 (2002), 229, 245.

${ }^{12}$ Fares Al-Braizat, "Muslims and Democracy: An Empirical Critique of Fukuyama's Culturalist Approach", International Journal of Sociology, Volume 43 (2002), 269, 292. See also, Nazih Ayubi, 1998, Political Islam: Religion and Politics in the Arab World, London: Routledge.

${ }^{13}$ John L. Esposito and John O. Voll, Islam and Democracy, New York: Oxford University Press, 1996.
} 
and civil decency in Indonesia is not civilisationally circumscribed. This simple and valuable wish will remain a powerful force in public politics and religion for years to come. ${ }^{14}$ Similarly, based on his field research during two years in 2001-2002 in Indonesia, Mujani found that Islam and Muslims, indeed, does not have a negative association with the components of democracy. On the contrary, almost all components of Islam have a positive and significant relationship with secular civic engagement, political engagement and political participation. These three components reinforce the democratic system as whole. Therefore, Islam helps Muslim citizens to be active in politics and this activity is congruent with the democratic system. ${ }^{15}$

Also, through his cross-national analysis in Kazakhstan and Turkey, Achilov depicts the fact that Islamic institutions which represented by Islamic educational, financial, and political institutions can coexist with basic elements of democracy, civil liberties and political rights and vice versa. Thus, Islam will continue to shape the democratisation process in Muslim politics for years to come. ${ }^{16}$ Even Akyol is sure that Islam is very compatible with the Western's capitalist economy supplemented by a set of moral values which stress the care of the poor and the needy, because Islam actually is a religion founded by a businessman where the Prophet Mohammad saw. was a successful merchant for the greater part of his live and one that has cherished trade since its beginning. ${ }^{17}$

${ }^{14}$ Robert W. Hefner, Civil Islam: Muslims and Democratization in Indonesia, Princeton and Oxford: Princeton University Press, 2000, xviii, 221.

15 Saiful Mujani, Religious Democrats: Democratic Culture and Muslim Political Participation in Post-Suharto Indonesia, PhD Dissertation, The Ohio State University, 2003, ii-iii, 334 350.

${ }^{16}$ Dilshod Achilov, Can Islam and Democracy Coexist? A Cross-National Analysis of Islamic Institutions in the Muslim World, PhD Dissertation, The University of Arizona, 2010, 217-224.

${ }^{17}$ Mustafa Akyol, "Islam is Compatible with Capitalism" in David M. Haugen, Susan Musser and Kacy Lovelace (Eds.) Islam Opposing Viewpoints, Farmington Hills: Greenhaven Press Akyol, 2009: 41. 
Two kinds of schools revealed that the relationship between Islam and democracy can be seen from multi-perspectives as long as it can be proved in the scholarly world. However, current evidences demonstrate that some majority of world Muslims live in electoral democracies such as India, Bangladesh, Indonesia, Nigeria and Turkey. In Bahrain, political reforms were begun after men and women voted in a referendum. In Iran, a discernible democratic ferment is challenging the restrictive measures imposed by the ruling clerics.

\section{Defining Islam and good governance}

There has been a common consensus in the recent world that good governance is an essential for human resource development in any society or state. Numerous international institutions such as World Bank, the United Nations of Development Program (UNDP) and the International Monetary Fund (IMF) play their vital roles to reach a democratic governance. The impact of this phenomenal notion is that Islam by and large is abandoned or deemed as alien from the reality. Thus, there are two different views among Muslim society and scholars concerning Islam and polity encompassing democracy and governance. Some argue that Islam as simply a religion without the right to govern or to order the daily affairs of human life. Others view that Islam is not merely a religion, but also a system and social order in all aspects of human life including the state and the law. ${ }^{18}$ Nonetheless, the fact that the failure of Muslim countries particularly in the Middle East and North Africa (MENA) regions in installing the democratic system revealed that political Islam embracing Islam as a religion is unable to maintain power and to create a new society. Thus, this section attempts to provide the relationship between Islam and good governance.

${ }^{18}$ Sayed Khatab and Gary D. Bouma, Democracy in Islam, London and New York: Routledge Khatab and Bouma, 2007, 7. 
Despite refer the Quran and Sunnah in defining good governance, it cannot be stated precisely that the two Muslims' sources left a definite method of electing a leader or successor. Yet, democracy, as a matter of fact, is a concept which have been borrowed from Islam. Muslims has bequeathed a set of scientific knowledge and civilisation to the world which were later de-Islamised and westernised, then a system of government which allows for the rule of law, sovereignty, equity and justice, human rights and mutual consultation should not have escaped the knowledge of the western world. The west grasped every good thing from the Muslims, secularised it before representing it to the rest of the world. ${ }^{19}$ Moreover, good governance can be defined as a bridge to strive in achieving justice in society, maintaining the dignity of individuals and protect group freedom, steering individuals towards achieving a means of sustainable livelihood before aspiring for other luxuries in social life. ${ }^{20}$

The model of good governance in Islam has been explaining in a set of stories on the leadership of God's apostles as mentioned in the Quran chapters. More obviously, Naqvi et al demonstrates that the story of Zulqarnain can be found in the Chapter 18 verse 83 to 101, the story of Moses and Haroon is in the Chapter 2 verse 40 and onwards, the story of Taloot is in the Chapter 2 verse 246 to 252, the story of Dawood is in the Chapter 38 verse 18 to 26 and in the Chapter 29 verse 15 to 45 , the story of Solomon is in the Chapter 38 and in the Chapter 29 verse 31 to 40, the story of Joseph is in the Chapter 12 verse 55 and onwards as well as the story of Muhammad can be traced in the Chapter 47 and in the

${ }^{19}$ R. Ibrahim Adebayo, "Islam, Democracy and Good Governance: A Glimpse of the Islamic Political Thought", ORITA Ibadan Journal of Religious Studies, XLII (2 December 2010), 1.

${ }^{20}$ Mazen Hashem, "Islamic Roots of Good Governance", Arab Insight, Volume 1, Number 1 (2007), 63. 
various chapters in the Quran. ${ }^{21}$ Additionally, Adebayo inserts that the Islamic model of governance was also depicted by Khularaur Rasyidin. ${ }^{22}$

Thus, Naqvi et al believe that the principal determinants of good governance in Islam are the leader's personality and his leadership skills which can dominate over and optimise the required institutional infrastructures. The leader has to be responsible to ensure all parameters and essentials required for maintaining good governance. Thus, we need the right leader who has a personal charisma and a sophisticated leadership skill to run the routine government affairs. Consequently, a state has to be ruled by leaders who have these criteria: having a commitment to earn God happiness and people welfare, an intellectual and fair commander, an effective planner, a rational policy maker, a thrifty financial manager, a distributor of justified taxation, a firm advocate of human rights, an astute defense planner, and an effective change manager causing revolution or evolution as applicable in societies. These requirements, indeed, demonstrate to the importance of a mechanism how to identify and elect the right leader of the government. ${ }^{23}$ Besides, Hashem is also sure that the peace and stability in Muslim countries are dependent on the collective ability to go beyond the repudiation authoritarian regimes and incompetent rulers. However, it depends on the approval of the majority of the society including non-religious individuals who accept Islam only as a civilisation, not identity. ${ }^{24}$

In the western world, the concept on good governance was developed primarily by a number of multilateral development institutions: World

${ }^{21}$ Imran Haider Naqvi et al., "The Model of Good Governance in Islam", African Journal of Business Management, Volume 5, Number 27 (2011), 10986-10988.

${ }^{22}$ R. Ibrahim Adebayo, "Islam, Democracy and Good Governance...", 4-10.

${ }^{23}$ Imran Haider Naqvi et al., "The Model of Good Governance in Islam...", 1099010991.

${ }^{24}$ Mazen Hashem, "Islamic Roots of Good Governance...", 71. 
Bank, UNDP and IMF. In accordance with this, World Bank attempts to set up good governance, synonymous with sound development management, as the manner in which power is exercised in the management of a country's economic and social resources for development. Good governance is central to create and sustain an environment which fosters strong and equitable development, and it is an essential complement to sound economic policies. Thus, the government plays a vital role in the provision of public goods and establishes the rules which make markets work efficiently and correct for market failure. In order to play this role, the government needs revenues and agents to collect revenues and produce the public goods. ${ }^{25}$

Similarly, UNDP words good governance as the exercise of economic, political, and administrative authority to manage a country's affairs at all levels. The economic governance encompasses the decision-making process which affect the country's economic activities and its relationships with other economies. The political governance is the process of decision-making to formulate policy. The administrative governance is the system of policy implementation. There are three actors of good governance: the state, the private sector, and civil society. These institutions should be designed to contribute to the sustainable human development. ${ }^{26}$ The result, UNDP assumes that democratic governance should embraces mechanisms, processes, and institutions which determine how power is exercised, how decisions are made on public issues, and how citizens articulate their interests, exercise their legal rights, meet their obligations, and mediate their differences. ${ }^{27}$

${ }^{25}$ World Bank, Governance and Development, Washington DC, 1992, 1.

${ }^{26}$ UNDP, Governance for Sustainable Human Development: A UNDP Policy Document, New York, 1997.

${ }^{27}$ UNDP, Democratic Governance Indicators and UNDP Human Development Reports: Framework Paper 3. Oslo: UNDP Oslo Governance Centre, 2010, 5. 
Meanwhile, IMF argues that good governance is a broad concept covering all aspects of the way a country is governed, embracing its economic policies and regulatory framework as well as adherence to the rule of law. IMF places a great stress on promoting good governance when providing policy advice, financial support, and technical assistance to its member countries. IMF also has strong measures in place to ensure integrity, impartiality, and honesty in the discharge of its own professional obligations. ${ }^{28}$ However, IMF has primarily concerns merely related with macroeconomic stability, external viability, and orderly economic growth in member countries. Its involvement in governance should be restricted to economic aspects of governance. ${ }^{29}$ Moreover, World Bank provides four major components of good governance: public-sector management, accountability, legal framework for development, and transparency and information. ${ }^{30}$ Meanwhile, good governance has nine fundamental characteristics. They are participation, rule of law, transparency, responsiveness, consensus orientation, equity, effectiveness and efficiency, accountability, and strategic vision. ${ }^{31}$

As was explored above, this study eventually defines good governance as the manner, strategy and bridge to strive human standard basic needs, social justice and stability as well as individual and group freedom by utilising local revenues and resources before aspiring further high needs. It can be reached only through the legal and elected government and other official democratic institutions which they are incorporating with private sectors and civil society. With respect to the features of good governance, it can be implied that it consists of participatory, law enforcement, ac-

\footnotetext{
${ }^{28}$ IMF, Factsheet: The IMF and Good Governance, Washington DC, 2014, 1.

${ }^{29}$ IMF, Good Governance: The IMF's Role, Washington DC, 1997, 3.

30 World Bank, Governance: The World Bank Experience, Washington DC, 1994, 1-36.

31 UNDP, Governance for Sustainable...
} 
countable, effective and efficient, transparent, responsive, predictable, equitable, and leadership.

With regard to the agenda of good governance, Islam concerns on the role and responsibility of leadership in ruling the state's resources. Word Bank concerns with the type of state regime in which power is exercised in the management of the economic and social resources, and the capacity of the government to formulate policies. UNDP dedicates itself to human development and political institution reform. IMF prefers to choose the reform of economic and social resource control. Nevertheless, they have same goals that the power has to be controlled by the right government to maintain the state's resources.

\section{Dealing with religious tolerance: policy, agenda and strategy}

Considering the actors of good governance consist of the state, the private sectors, and the civil society, this study attempts to examine religious tolerance as one of the indicators to reach good governance due to its relation with political and cultural life within society. Indonesia contains at least six main religions: Islam, Christians, Catholics, Buddhists, Hindu, Confucians and various beliefs. Islam as a dominant religion and others are minority. In particular case, Islam is a tiny religion in some provinces such as in Bali, North Sulawesi, East Nusa Tenggara and Papua. Therefore, based on one of the characteristics of the good governance that realising human development should involve the participation and equity among civil society so that it is a common responsibility to obtain stability and to remove differential colours among society whether religion, tribe, or ethnic.

In Islam, the concept of tolerance can be called as "al-tas£muh". Various chapters in Al-Qur'an explicitly encourage tolerance and reject intolerance. As a peaceful religion, Islam forcefully refuses all patterns of vio- 
lence such as terrorism, suicide booms, and killing humans. The Islamic tradition teaches us that peace is reached through tolerance, forgiveness, and responding to evil with good. Thus tolerance is closely correlated with social activities. ${ }^{32}$ Literally, tolerance means to endure or bear. This concept in the Western political theory is applied for the first time to religious movements, then political beliefs and practices, finally, social and economic theories as well as ethnic ways of life. ${ }^{33}$ Thus, the definition of tolerance is to approving people and allowing their practices even when we strongly refuse them. Therefore, the tolerance consists of an attitude which is intermediate between wholehearted acceptance and unrestrained opposition. In the context of religious tolerance, it is nonetheless a risk policy with high stakes and difficult to be sustained even in a stable constitutional democracy. ${ }^{34}$ Moreover, the attitude of tolerance can be seen as the foundation for a democratic accord and as the key word for coping with diversity. ${ }^{35}$

The term "religious tolerance" is an attitude of respect towards other religions and beliefs. It is also an implication of religious pluralism. In general, religious tolerance signifies the indulgence or forbearance in judging the opinions, customs, or acts of others as well as freedom from bigotry or from racial or religious prejudice. ${ }^{36}$ Moreover, Little also pro-

\footnotetext{
${ }^{32}$ Mohammad Ahmed Qodri, Peace and Tolerance in Islam, Unpublished Monograph, May 2004, 5.

${ }^{33}$ Russell F. Farnen, "Destroying Tolerance: The Dangers of (Neo) Nationalism and (Neo) Racism”, in Russell F. Farnen, Karl Peter Fritzsce, et al. (Eds.) Tolerance in Transition, Oldenburg: Bibliotheks-und Informationssystem der Universität Oldenburg, 2001, 25.

34 TM. Scanlon, The Difficulty of Tolerance: Essays in Political Philosophy, Cambridge: Cambridge University Press, 2003, 187, 200-201.

35 Thomas R. Henschel, "Conclusion: Changing the Paradigm in Tolerance Education", in Russell F. Farnen, Karl Peter Fritzsce, et al (Eds.) Tolerance in Transition, Oldenburg: Bibliotheks-und Informationssystem der Universität Oldenburg, 2001, 183-184.

${ }^{36}$ Zainul Fuad, Religious Pluralism in Indonesia Muslim-Christian Discourse, PhD Dissertation, Universität Hamburg, 2007, 100.
} 
vides an obvious concept that religious tolerance is a response to a set of beliefs, practices or attributes, initially regarded as deviant or objectionable, with disapproval, but without using force or coercion. ${ }^{37}$ This means that tolerance is only possible in the context of disagreement. If all religions are considered the same in value, or their differences are not to be taken seriously, then there is no significance of tolerance. To tolerate other religions or belief is actually to respects the right of others to free will to choose what to believe. In doing so, one is regarded tolerant when one respects the rights of others to hold different religious beliefs. $\mathrm{He}$ might regard the other beliefs false, but he is still regarded tolerant if he acknowledges that others have the right to follow freely their faith's beliefs and practices. ${ }^{38}$

\section{Policy}

In his analysis, Fuad provides Nurcholish Madjid's thoughts that Muslims have shown their inclusiveness and tolerance towards other religious communities in the earlier periods, even Muslims to be the first among religious communities to recognise the rights of the adherents of other religions to participate fully in the public activities of the state. The "Madina Charter", a political document made by the Prophet Mohammad, is a tangible that Muslims and non-Muslims were united within a bond of civility. This constitution embraced principles of religious freedom, the right for each group to govern the life in accordance with his belief, the freedom in economic and political relations between the groups, the obligation to participate in the defence against the en-

${ }^{37}$ David Little, "Rethinking Religious Tolerance: A Human Right Approach", in David Little and David Chidester (Eds.) Religion and Human Rights: Toward an Understanding of Tolerance and Reconciliation, Atlanta: Emory University, 2001, 9.

${ }^{38}$ Zainul Fuad, Religious Pluralism..., 101. 
emies and the like. ${ }^{39}$ In the context of Indonesia, Madjid formulates a brilliant notion under the term "Masyarakat Madani" to emphasise the similar reality under the Madina Charter. ${ }^{40}$ In this sense, Madjid forcefully underpins Pancasila and the 1945 Constitution as a common platform among distinctive religions in Indonesia. ${ }^{41}$

Meanwhile, Abdurrahman Wahid's ideas concerning religious tolerance is that the most essential meaning of democracy is protecting and defending the rights of minority groups. ${ }^{42}$ Moreover, Wahid assumes that religion should serve its transformative function for social life and formulate its concept on human dignity, equal status of humankind before law, and true solidarity among human beings. Every religion should integrate with other faiths in chasing a number of universal basic values and in serving society in the most real forms such as alleviating poverty, upholding sovereignty of law, and ensuring the freedom of expression. Along with Majid, Wahid also stresses the importance of Pancasila for maintaining interreligious relations. ${ }^{43}$ Additionally, refers to Shihab, it is also vital to mention that interreligious dialogue is extremely urgent to build religious tolerance. The dialogue is not to denote who will be the winner, but to understand the other according to the belief they adhere. No any groups in the dialogue can claim as the truest side since each of them has the potential both to be true and to be wrong. ${ }^{44}$ Refers to Fuad's findings,

\footnotetext{
39 Zainul Fuad, Religious Pluralism..., 127-128.

${ }^{40}$ Nurcholish Madjid, "Urbanism in Islam and Indigenous Enterpreneurship", Mizan, Volume III, Number 2 (1990): 54.

${ }^{41}$ Nurcholish Madjid, Cita-cita Politik Islam Era Reformasi, Jakarta: Paramadina, 1999, 57.

42 Anonymous, "Demokrasi Wahid”, Panji Masyarakat, Number 682 (1-10 May 1991), 24-26.

43 Abdurrahman Wahid, "Agama dan Demokrasi", in Th Sumartana et al. (Eds.) Spiritualitas Baru: Agama dan Aspirasi Rakyat, Yogyakarta: Dian Interfidei, 1994, 273.

${ }^{44}$ M. Quraish Shihab, "Reaktualisasi dan Dialog Antar Agama-agama" in Meretas Jalan Teologi Agama-agama di Indonesia, Jakarta: BPK Gunung Mulia, 2000, 150.
} 
the notion of interreligious dialogue and the significance of Pancasila and the 1945 Constitution for implementing religious tolerance are also reinforced by some prominent Indonesian Catholic and Christian theologians such as JB Banawiratma, Franz Magnis-Suseno, and Eka Darmaputera. ${ }^{45}$

\section{Agenda}

Considering Muslim and non Muslim perspectives above, it can be implied that concerning agenda for religious tolerance is threefold. First is interreligious dialogue. The dialogue is a precise way for solving any problems, because dialogue is a space for all involved stakeholders to share and discuss what the main causes and what the right way to solve it. Inasmuch as Indonesia has at least six main religions and various local beliefs, the interreligious dialogue among society will find the proper way to deal with different worship in daily life. As the result, if society can understand any differences among them, the tolerance and pluralism attitudes will emerge in people personality and how they are respecting each other.

Second is promoting and realising civic education and Pancasila values as well as the 1945 Constitution among society. Five principles in Pancasila and the 1945 Constitution is a universal and excellent value which shades diversity among society, therefore, "Bhinneka Tunggal Ika" (Unity in Diversity) is an official motto for past, present, and future Indonesian life. The most important is Indonesian citizens have to understand, teach to others, and realise the both guide for daily activity, everywhere and every time they are. Consequently, Pancasila and the 1945 Constitution have to be main guide for their life, attitudes, behaviours, and worldview. Third is having a direct role to tackle kinds of case of religious tolerance such as become a mediator between two or more parties, avoiding further physical violence as well as finding best solution for the case. Impor-

45 Zainul Fuad, Religious Pluralism..., 159-207. 
tantly, recovering women and children is a priority agenda after the conflict occurred.

\section{Strategy}

This study offers two main strategies to implement the agendas above. First is education through both formal and non-formal ways. The formal education can be found in schools, colleges, universities and the like. The most important is not only how to teach and transfer of knowledge, but also how to deliver applicable and real attitudes to pupils, students, and participants' personality so that they have good understanding and attitudes in their daily life. With respect to non-formal education, it can be seen in outside the formal education such as in the family and social interactions. In this sense, the role of family embracing parents and grandparents are extremely fundamental to educate their children on how to do something whether attitudes, behaviours, or customs in social life. Participating in trainings, seminars, and other similar events which correlated with two agendas above are part of non-formal education.

Second is supporting social activities. This strategy consists of a set of non-profit and charitable actions. It can be found in activities under the term of kerja bakti (social working) such as together with other people cleaning up surrounding the village every Sunday morning, or arisan which denotes to rotating savings and credit association, a form of microfinance. Arisan is typically carried out by female although male can make similar deeds. Other instances are fulfilling the invitation, e.g. the marriage party, kinds of syukuran or kenduri (a party as a thanksgiving due to getting the happiness or wealth) or participating in particular competitions such as tujuhbelasan in the village (a traditional competition for the Independence celebration) and other sorts of local competitions. 


\section{Addressing gender equality: policy, agenda and strategy}

One of the debatable discourses among Muslim scholars and society is concerning gender equality. It was caused by one of the verses in the Quran (the Chapter 4 verse 34) which stated that: "Men are the protectors and maintainers (qowwamuna) of women, because Allah has made one of them to excel the other, and because they spend (to support them) from their means". Meija interprets that this verse has frequently taken to mean that men have an authority over women because they are superior over women physically and intellectually and because they provide for the women. If women are less than men and they are being provided for by their husbands, men should guide the women. This basically rules out the claim that men have the authority over women in all matters, even in those that they are not qualified. If the above verse is read as men having authority over women, it would contradict other verses in Al-Qur'an (the Chapter 9 verse 71) which stated: "The believers, men and women, are protectors (awilya) one of another." How can men be superior over women if men and women are supposedly protectors of one another? Interpreted in this way, the Chapter 4 verse 34 could also imply that women can advise or handle the affairs of their husbands in matters where they are more qualified, e.g. if the woman is a corporate lawyer and her husband is a businessman, clearly she is in a better position to give him legal advice. This conclusion is in line with the above verse that men and women are awilya of one another. ${ }^{46}$ Besides, Al-Qur'an also has portrayed the victory of Queen of Bilqis in leading of the Sheba state. It is a tangible that Islam definitely reinforces the equity of men and women. ${ }^{47}$

\footnotetext{
${ }^{46}$ Melanie P. Mejia, “Gender Jihad: Muslim Women, Islamic Jurisprudence and Women's Rights”, Kritikç, Volume 1, Number 1 (2007), 11-12.

${ }^{47}$ Barbara Freyer Stowasser, Women in the Qu'ran, Traditions, and Interpretation, Oxford: Oxford University Press, 1994, 62-66.
} 
The concept of equality basically denotes to all differences are obscured with the result that all human beings are considered to be alike. Thus, women and men are commensurate and similar individuals. ${ }^{48}$ In addition, the equal treatment for men and women can be found in verses of Al-Qur'an which discussing property (4:32), labor (3:195), reward for righteous living (16:97, 4:124, 40:40), religious obligations (9:71), punishment for theft (5:38) and adultery (24:2) and modesty (24:30-31). Some jurists claim that these verses establish the equality of men and women. Nevertheless, gender equality in the Muslim world will remain a complex problem for some times to come. Part of the problem is the distinction between the theory and reality of male and female relations. Customary practices portray discrepancies in the ways Muslims follow the prescriptions on women in Islamic law. ${ }^{49}$

Yet, Spierings et al are optimistic that the gender equality in Muslim countries will be attained by providing the political opportunity structures particularly for women. ${ }^{50}$ Moreover, Kadivar argues although women physically and psychologically differ from men, both of them have equal rights because they are human. ${ }^{51}$ Thus, Shahid is sure that Muslims will realise to modify their views on women in a more progressive manner. Sooner or later they will adhere to the Islamic message which respects this gender in every social relation. As a mother she is being placed above all other human relations, as a daughter she guarantees paradise to par-

48 Tuija Parvikko, "Conceptions of Gender Equality: Similarity and Difference", in Elizabeth Meehan and Selma Sevenhuijsen (Eds.) Equality Politics and Gender, London: SAGE Publications Ltd, 1991, 36-37.

${ }^{49}$ Donna Lee Bowen, "Islamic Law and the Position of Women", in Stephen P. Heyneman (Ed.) Islam and Social Policy, Nashville: Vanderbilt University Press, 2004, 52, 110.

${ }^{50}$ Niels Spierings et al., "On the Compatibility of Islam and Gender Equality: Effects of Modernization, State Islamization, and Democracy on Women's Labor Market Participation in 45 Muslim Countries", Soc Indic Res, Volume 90 (2009), 503.

${ }^{51}$ Mohsen Kadivar, "Revisiting Women's Rights in Islam", in Ziba Mir-Hosseini et al (Eds.) Gender and Equality in Muslim Family Law, New York: IB Tauris \& Co Ltd, 2013: 232. 
ents, and as a wife she is being protected and an equal partner to her husband. ${ }^{52}$ Likewise, World Bank believes that if the rights of men and women are flagrantly unequal, it is very difficult to establish a democratic and participatory sociopolitical order and an environment of equal opportunity. Additionally, the more extreme manifestations of power inequality between men and women constitute gross violations of human rights. The official national censuses' finding shows that as a result of excess female mortality, about seven percent of girls under age five are "missing" in China and Korea and more than four percent in India and other parts of South Asia. Without such discrimination there would be an estimated 60-100 million more women in the world. ${ }^{53}$

\section{Policy}

Based on Islamic teachings, there are some key principles regarding gender equality. First, men and women have the same spiritual human nature. Second, both genders are recipients of the divine breath since they are created with the same human and spiritual nature. Third, both genders are dignified and are trustees of Allah on earth. Fourth, men and women have the same religious and moral duties and responsibilities. They both face the consequences of their deeds. Fifth, nowhere how AlQur'an states that one gender is superior to the other. Some mistakenly translate qowwamuna or responsibility for the family as superiority. AlQur'an makes it clear that the sole basis for superiority of any person over another is piety and righteousness not gender, color, or nationality. Seventh, the absence of women as prophets or Messengers of Allah in prophetic history is due to the demands and physical suffering associated

\footnotetext{
${ }^{52}$ Kamran Shahid, "Feminism and Islam: Contextualizing Equality of Gender in Islam", Pakistan Journal of History Eु Culture, Volume XXVIII, Number 1 (2007), 153.

53 World Bank, World Development Report 2000/2001: Attacking Poverty, Oxford: Oxoford University Press, 2001, 118.
} 
with the role of messengers and prophets and not because of any spiritual inferiority. ${ }^{54}$

Likewise, World Bank promotes continuously gender equality to the world because unequal gender relations are part of the broader issue of social inequities. Thus, the lack of autonomy of women has significant negative consequences for the education and health of children. Moreover, World Bank posits that gender inequality has strong repercussions for human capital in the next generation, because the burden of bearing and rearing children falls largely on women. Uneducated women will face serious constraints in rearing healthy and productive children. They also tend to have more children than they wish. In contrast, educated women are able to communicate better with their spouse about family size decisions, use contraception more effectively, and have higher aspirations for their children. Studies in China, India, the United Kingdom, and the United States show that mother's education improves child survival and cognitive development. Microcredit programs in Bangladesh find that giving income-generating loans to women improves the nutritional status of their children, a result that does not hold for men. Education and autonomy reinforce each other. Women with more education and greater domestic autonomy are better able to nurture and protect their children. ${ }^{55}$

\section{Agenda}

Based on the concept and policy which was explained above, it can be formulated that the first and foremost Muslim agenda to promote the gender equality is re-examining Islamic teachings in Al-Qur'an and AsSunnah with excellent and in-depth perspectives that gender equality is a

\footnotetext{
54 Jamal A. Badawi, Gender Equity in Islam, Unpublished Paper, 28 June 2014, 1-4.

55 World Bank, World Development Report 2000/2001..., 9-10, 119.
} 
part of humanism values. Therefore, in studying Islam, Muslims have to learn comprehensively not partially by using common sense that Islam is an entire and peaceful religion not only for men, but also for women, animals, and the natural world.

It is in line with the agenda of gender mainstreaming. It can be defined as the process of assessing the implications for women and men of any planned action, including legislation, policies or programmes, in any areas and at all levels. It is a strategy for making women's as well as men's concerns and experiences an integral dimension of the design, implementation, monitoring and evaluation of policies and programmes in all political, economic and societal spheres so that women and men benefit equally and equality is perpetuated. To achieve this agenda, UNDP has launched a global gender programme which focuses on the following key areas. First, research, training and monitoring to strengthen substantive know-how for integration of gender issues into SHD areas. Second, practical application of SHD approaches and gender equality concepts. Third, gender mainstreaming of experimentation, good practices and lessons learned. Fourth, improved management and availability of information about gender at UNDP. Fifth, communication and networking for global/ regional/national synergies and partnerships. Sixth, UNDP/UNIFEM (The United Nations Development Fund for Women) cooperation at the country level especially in follow-up to the world conferences. Seventh, training and back-stopping for UNDP gender focal points in country offices. ${ }^{56}$

Meanwhile, the World Bank offers that the greater gender equality is desirable in its own right. Although there has been progress such as in education and health, but much more needs to be done. A mix of politi-

${ }^{56}$ Nilüfer Cagatay, Gender and Poverty: Working Paper Series. Social Development and Poverty Elimination Division, United Nations Development Programme, May 1998, 14 15. 
cal, legal, and direct public action is required. Thirty-two countries, from Argentina to India, have measures to promote women's representation in local and national assemblies, and this is already transforming women's ability to participate in public life and decision making. Some countries correct gender biases in the law, as in the 1994 Colombian Agrarian Law. Utilising public resources to subsidise girls' education has been demonstrated to pay off in Bangladesh and Pakistan. A range of measures in productive activities, notably microfinance and farming inputs, have produced documented benefits in terms of increased yields (for instance, in Kenya) and increased autonomy for women and better nutritional status of children (in Bangladesh and in virtually every setting where this issue has been examined). ${ }^{57}$

\section{Strategy}

Applying Bowen's offers, there are two strategies to implement the agenda of gender equality. First is education. Although Islam firmly declares that education is for all, many Muslim countries not give educational opportunities and facilities to women to the same extent as to men. Islam actually emphasises the importance of education for all Muslims whether they are men or women as stated in a popular hadits: "Seek education, even if it be in China." Another hadits reinforces the role of the father in educating his daughters: "The father, if he educates his daughter well, will enter paradise." Another popular saying attributed to Al-Shawki states, "A mother is a school. If she is educated, than a whole people are educated." Thus, education holds a vital place in how Islam itself is perceived. A research on family planning in the Middle East shows that more educated ulama tend to be far more open to family-planning measures than

57 World Bank, World Development Report 2000/2001..., 9-10.

${ }^{58}$ Donna Lee Bowen, "Islamic Law and the Position of Women...", 55. 
poorly educated, local-level religious leaders. Second is increasing women's economic status. A major principle in Islam is equality among society. The treatment of women and children as well as reformation of the institution of slavery were important elements by establishing an ethical and viable social order. The Prophet of Muhammad criticised Meccan society for its disregard for the welfare of its weaker members. ${ }^{58}$

Likewise, Beneavot argues that the primary education affects two important groups who are traditionally unincorporated in society and are thought to have minimal competencies in public life: women and children. In fact, the education of female has a positive impact to the economic growth. Thus, the education for females has crucial effects for the economies of Third World states. ${ }^{59}$ Moreover, according to World Bank, women make significant contributions to economic and social development. Expanding their opportunities in the public and pri-vate sectors is a core development strategy, and education is the starting point. By enrolling and staying in a school, girls gain skills to enter the labor market, care for families and make decisions for themselves. The result, poor households are less likely than wealthy households to keep their children in school and girls from wealthier households are more likely to enroll in school and stay longer. ${ }^{60}$ Thus, World Bank posits that more equitable distribution of opportunities and resources between men and women also leads more directly to higher economic growth and productivity. Cross country analysis indicates that countries which invest in girls' education have higher rates of economic growth. ${ }^{61}$

\footnotetext{
59 Aaron Beneavot, "Education, Gender, and Economic Development: A Cross-National Analysis", in Julia Wrigley (Ed.) Education and Gender Equality, London and Washington DC: The Falmer Press, 1992: 41-42.

${ }^{60}$ World Bank, World Development Indicators 2014, Washington DC, 2014: 4.

${ }^{61}$ World Bank, World Development Report 2000/2001..., 119.
} 


\section{Conclusion}

This study is going to provide two comparative perspectives in dealing with religious tolerance and gender equality issues namely Islam and good governance. As was explained earlier, Islam and good governance have similar doctrines in coping with those two public issues. Among of them is neither opposite tenets nor conflicting teaching. Thus, there are two main findings will be presented in this conclusion. First is in the case of religious tolerance, the precise policy is two things. First is building society's consciousness on the significant of religious tolerance through interfaith dialogues. Second is requiring a common platform which has universal values on unity in diversity. The agendas are three things. First is carrying out interreligious dialogues. Second is disseminating civic education, Pancasila and the 1945 Constitution. Third is involving in tackling kinds of case of religious tolerance. Meanwhile, there are two main strategies. First is education both formal (schools and colleges) and non-formal (trainings and seminars). Second is supporting to any positive and constructive social activities.

The second finding is that in the case of gender equality, the policy to deal with this issue is that men and women are initially equal humans in various perspectives whether religious, social, economical, or political. Besides, unequal attitudes and facilities to women will affect significantly to human life development as a whole. For the agendas, there are three points: Deepening Islamic teachings on gender, mainstreaming gender issues to public through trainings and the like and become a part of one of actors who handle the cases of gender equality. In the meantime, the strategies are three-fold: Involving women/girls to education systems both formal and non-formal ways, increasing women's economic status and involving women in policy making. 
To sum up, Islam and good governance perspectives have similar and integrated policy, agenda and strategy in addressing religious tolerance and gender equality. There are no conflicting doctrines between Islam and western values. Thus, Muslims have to promote this notion to the world. Lastly, it is interesting to be examined for further in-depth researches why conflict among religions is still in high temperature? It is also important to note that a lot of Muslims refuse the notion of gender equality. Why among those Muslims have different perspectives with this issue?

\section{Bibliography}

Achilov, Dilshod. Can Islam and Democracy Coexist? A Cross-National Analysis of Islamic Institutions in the Muslim World. PhD Dissertation. The University of Arizona, 2010.

Adebayo, R. Ibrahim, "Islam, Democracy and Good Governance: A Glimpse of the Islamic Political Thought", ORITA Ibadan Journal of Religious Studies, XLII (2 December 2010): 1-24.

Akyol, Mustafa, "Islam is Compatible with Capitalism", in David M. Haugen, Susan Musser, and Kacy Lovelace (Eds.) Islam Opposing Viewpoints. Farmington Hills: Greenhaven Press, 2009.

Al-Braizat, Fares, "Muslims and Democracy: An Empirical Critique of Fukuyama's Culturalist Approach", International Journal of Sociology, Volume 43 (2002): 269-299.

Anonymous, "Demokrasi Wahid", Panji Masyarakat, Number 682 (1-10 May 1991).

Ayubi, Nazih. Political Islam: Religion and Politics in the Arab World. London: Routledge, 1998.

Badawi, Jamal A. Gender Equity in Islam. Unpublished paper. 28 June 2014.

Beneavot, Aaron, "Education, Gender, and Economic Development: A CrossNational Analysis", in Julia Wrigley (Ed.) Education and Gender Equality. London and Washington DC: The Falmer Press, 1992.

Bowen, Donna Lee. "Islamic Law and the Position of Women", in Stephen P. Heyneman (Ed.), Islam and Social Policy. Nashville: Vanderbilt University Press, 2004. 
Cagatay, Nilüfer. Gender and Poverty: Working Paper Series. Social Development and Poverty Elimination Division, United Nations Development Programme, May 1998.

Dye, Thomas R. Understanding Public Policy. Fifth Edition. Englewood Cliffs, N.J.: Prentice-Hall, 1984.

Esposito, John L. and John O. Voll. Islam and Democracy. New York: Oxford University Press, 1996.

Farnen, Russell F., "Destroying Tolerance: The Dangers of (Neo) Nationalism and (Neo) Racism”, in Russell F. Farnen, Karl Peter Fritzsce, et al. (Eds.) Tolerance in Transition. Oldenburg: Bibliotheks-und Informationssystem der Universität Oldenburg, 2001.

Fish, M. Steven, "Islam and Authoritarianism", World Politics, Volume 55 (October 2002): 4-37.

Fuad, Zainul. Religious Pluralism in Indonesia Muslim-Christian Discourse. PhD Dissertation. Universität Hamburg, 2007.

Fukuyama, Francis, The End of History and the Last Man. New York: Three Free Press (A Division of Macmillan, Inc.), 1992.

Fukuyama, Francis, “The West Has Won: Radical Islam Can't Beat Democracy and Capitalism", The Guardian (11 October 2001).

Hashem, Mazen, "Islamic Roots of Good Governance", Arab Insight, Volume 1, Number 1 (2007): 63-71.

Hefner, Robert W. Civil Islam: Muslims and Democratization in Indonesia. Princeton and Oxford: Princeton University Press, 2000.

Henschel, Thomas R., "Conclusion: Changing the Paradigm in Tolerance Education”, in Russell F. Farnen, Karl Peter Fritzsce, et al (Eds.) Tolerance in Transition. Oldenburg: Bibliotheks- und Informationssystem der Universität Oldenburg, 2001.

Huntington, Samuel P., "Will More Countries Become Democratic?", Political Science Quarterly, Volume 99 (1984): 193-218.

Huntington, Samuel P. The Third Wave: Democratization in the Late Twentieth Century. Norman: University of Oklahoma Press, 1991.

IMF. Factsheet: The IMF and Good Governance. Washington DC, 2014.

IMF. Good Governance: The IMF's Role. Washington DC, 1997.

Jenkins, W.I. Policy Analysis: A Political and Organizational Perspective. New York: St. Martin's Press, 1978.

Kadivar, Mohsen, "Revisiting Women's Rights in Islam”, in Ziba Mir-Hosseini et al (Eds.) Gender and Equality in Muslim Family Law. New York: IB Tauris \& Co Ltd, 2013. 
Kedourie, Elie. Politics in the Middle East. Oxford: Oxford University Press, 1992.

Khatab, Sayed and Gary D. Bouma. Democracy in Islam. London and New York: Routledge, 2007.

Lewis, Bernard. What Went Wrong? Western Impact and Middle Eastern Response. Oxford: Oxford University Press, 2002.

Little, David, "Rethinking Religious Tolerance: A Human Right Approach", in David Little and David Chidester (Eds.) Religion and Human Rights: Toward an Understanding of Tolerance and Reconciliation. Atlanta: Emory University, 2001.

Madjid, Nurcholish, "Urbanism in Islam and Indigenous Enterpreneurship", Mizan, Volume III, Number 2 (1990).

Madjid, Nurcholish. Cita-cita Politik Islam Era Reformasi. Jakarta: Paramadina, 1999.

Mejia, Melanie P., "Gender Jihad: Muslim Women, Islamic Jurisprudence, and Women's Rights", Kritikç, Volume 1, Number 1 (2007): 1-24.

Moussalli, Ahmad S. The Islamic Quest for Democracy, Pluralism, and Human Rights. Gainesville, FL: University Press of Florida, 2001.

Mujani, Saiful. Religious Democrats: Democratic Culture and Muslim Political Participation in Post-Suharto Indonesia. PhD Dissertation. The Ohio State University, 2003.

Naqvi, Imran Haider, et al., "The Model of Good Governance in Islam", African Journal of Business Management, Volume 5, Number 27 (2011): 1098410992.

Norris, Pippa and Ronald Inglehart, "Islamic Culture and Democracy: Testing the Clash of Civilizations' Thesis”, in Ronald Inglehart (Ed.) Human Values and Social Change. Findings from the Values Surveys. Leiden: Brill, 2003.

Parvikko, Tuija. "Conceptions of Gender Equality: Similarity and Difference", in Elizabeth Meehan and Selma Sevenhuijsen (Eds.) Equality Politics and Gender. London: SAGE Publications Ltd, 1991.

Qodri, Mohammad Ahmed. Peace and Tolerance in Islam. Unpublished monograph, May 2004.

Scanlon, TM. The Difficulty of Tolerance: Essays in Political Philosophy. Cambridge: Cambridge University Press, 2003.

Shahid, Kamran, "Feminism and Islam: Contextualizing Equality of Gender in Islam", Pakistan Journal of History $\mathcal{E}$ Culture, Volume XXVIII, Number 1 (2007): 121-153. 
Shihab, M. Quraish. "Reaktualisasi dan Dialog Antar Agama-agama" in Meretas Jalan Teologi Agama-agama di Indonesia. Jakarta: BPK Gunung Mulia, 2000.

Spierings, Niels, et al., "On the Compatibility of Islam and Gender Equality: Effects of Modernization, State Islamization, and Democracy on Women's Labor Market Participation in 45 Muslim Countries", Soc Indic Res, Volume 90 (2009): 503-522.

Stowasser, Barbara Freyer. Women in the Qu'ran, Traditions, and Interpretation. Oxford: Oxford University Press, 1994.

Tessler, Mark, "Do Islamic Orientations Influence Attitudes toward Democracy in the Arab World: Evidence for the World Values Survey in Egypt, Jordan, Morocco, and Algeria", International Journal of Comparative Sociology, Volume 43 (2002): 229-249.

UNDP. Democratic Governance Indicators and UNDP Human Development Reports: Framework Paper 3. Oslo: UNDP Oslo Governance Centre, 2010.

UNDP. Governance for Sustainable Human Development: A UNDP Policy Document. New York, 1997.

Wahid, Abdurrahman. "Agama dan Demokrasi", in Th Sumartana et al. (Eds.) Spiritualitas Baru: Agama dan Aspirasi Rakyat. Yogyakarta: Dian Interfidei, 1994.

World Bank. Governance and Development. Washington DC, 1992.

World Bank. Governance: The World Bank Experience. Washington DC, 1994.

World Bank. World Development Indicators 2014. Washington DC, 2014.

World Bank. World Development Report 2000/2001: Attacking Poverty. Oxford: Oxoford University Press, 2001. 
